\title{
Ex situ conservation of endangered plant species of Latvia by slow growth storage
}

\author{
Dace K!̣aviṇa ${ }^{1 *}$, Dārta Kḷaviņa² \\ ${ }^{1}$ National Botanic Garden of Latvia, Miera 1, Salaspils LV-2169 Latvia \\ ${ }^{2}$ Latvian State Forest Research Institute "Silava", Rigas 111, Salaspils LV-2169, Latvia \\ *Corresponding author, E-mail: dace.klavina@nbd.gov.lv
}

\begin{abstract}
Ex situ conservation of endangered plant species is the main objective of work of the Department of Ecophysiology of the National Botanic Garden of Latvia. In order to create a gene bank in tissue culture, use of appropriate methods for long-term preservation of living plant material is important. The objective of this study was to found ways to limit rate of shoot growth and to maximize the vitality period of shoot cultures. Several endangered plant species with high multiplication rate and sufficient number of explants were chosen for slow growth experiments. Murashige and Skoog medium supplemented with 1 to 6\% carbohydrates (sucrose, sorbitol, mannitol), activated charcoal, and, for some species, cytokinin or other ingredients was used. After planting explants in experimental media, cultures were kept for four to five weeks at $25^{\circ} \mathrm{C}$, later at $5{ }^{\circ} \mathrm{C}$. To evaluate explant growth in relation to various media conditions and genotype, root structure was analyzed using the program Win RHIZO 2002 C. Reduced shoot and root growth was observed for 23 species with sorbitol (for example, Armeria maritima, Galium tinctorium, Spergularia salina) and for eight species with mannitol (for example, Dianthus arenarius, Hydrocotile vulgaris, Juncus gerardii). Few species grew only on sucrose-containing medium. At $5^{\circ} \mathrm{C}$, most species survived for 24 and more months of storage without subcultivation. Some influence of storage medium composition on shoot first re-growth after storage was observed, but all cultures retained growth capacity after storage.
\end{abstract}

Key words: storage, endangered plants, in vitro conservation, polyols.

Abbreviations: BA, benzyladenine; MS, Murashige and Skoog.

\section{Introduction}

There are various approaches for achieving the current targets of the Global Strategy for Plant Conservation for species conservation. Besides species conservation in situ, also ex situ preservation including in vitro banks of taxa is being widely promoted. International Botanic Gardens programmes emphasize that botanic gardens should be the centres of ex situ conservation of plant species and elaborate ex situ conservation protocols for all groups of vascular plants. Alongside with seed banks, tissue culture technology is an additional way for saving biological diversity ex situ (Bramwell 1990).

The National Botanic Garden of Latvia started to elaborate ex situ conservation methods for threatened species of Latvia in 2003 (Kḷaviņa et al. 2004). There are several methods for long-term and slow-growth conservation: cultivation of shoot cultures at low temperature and variation of media components. Successful combination of these factors ensures reduced growth rate of particular species together with extended subculture period. Temperature for in vitro storage depends on plant species; differences in appropriate storage temperatures among species might be related to the cold hardiness of a particular plant (Lambardi et al. 2006; Joshi, Jadhav 2013).
Cultivation at low temperature can be used for plant species of the temperate zone origin, because of their natural cold tolerance. Increased sucrose concentration in cultivation medium usually stimulates in vitro growth (Voračkova et al. 1998) and allows for long-term preservation success of woody plants (Kḷavina, Ievinsh 2008). For various perennials, a standard sucrose concentration of 2 to $3 \%$ in media is usually used.

Variation of mineral element concentration in media and use of abscisic acid and osmotic growth retardants can allow to find the most appropriate medium composition. Polyols or sugar alcohols, mainly mannitol and sorbitol, are essential components that can significantly reduce growth in certain plant cultures (Flecher 1994; Lipavska, Vreugdenhil 1996; Negash et al. 2001; Preira et al. 2003; Charoensub, Phansiri 2004; Ankita, Animesh 2013; Joshi, Jadhav 2013; Ghahery et al. 2015). Polyol media amendments are generally considered to be metabolically inert, and in vitro polyol-dependent phenomena are defined predominantly as mere osmotic effects (Steinitz 1999). Polyols may serve as reserve carbohydrates, but also as sinks for photosynthetically produced reducing compounds. The physiological role of polyols as agents of translocation and endogenous osmoregulation has been considered, together with more biochemical aspects of 
their utility, and for co-enzyme regulation (Lewis, Smith 1967; Mioti et al. 2009). Mannitol is readily taken up by plants and transported to shoots rather quickly. As there are probably great differences in the ability of various plants to accumulate mannitol and use it as a source of carbon and energy, it is necessary to test the response of particular plant (Lipavska, Vreugdenhil 1996).

The aim of the current study was to test effect of media with polyols on cold storage of in vitro cultures of threatened plant species.

\section{Materials and methods}

For in vitro storage, microcuttings were transferred to modified Murashige-Skoog medium (MS) to test efficiency of different cultures for inducing slow growth. For experiments, in vitro cultures of endangered plant species of Latvian wild origin were used (totally 47 species). All of the used species showed good regeneration and propagation potential of earlier established cultures (Kl̦aviña et al. 2004; 2006). Storage results were obtained for 32 species (Table 1). Shoot type or rosette explants of species without growth regulators in previous subculture were cultivated on MS medium (with half reduced nitrate content) with plant agar $6 \mathrm{~g} \mathrm{~L}^{-1}, \mathrm{pH} 5.8$, sucrose 1 to $6 \%$ and metabolically inactive carbohydrates sorbitol and mannitol in concentration 1 to $4 \%(\mathrm{w} / \mathrm{v})$ as the sole carbon source or with sucrose $(0.1,0.5$, $1,2$ or $3 \%)$ together with sorbitol or mannitol in cases when explants did not grew on polyol alone (Table 1). Various other additives were tried depending on requirement of species: activated charcoal 0.075 to $0.1 \%$, sodium chloride (100 to $200 \mathrm{mM}$ ), cytokinin ( 0.1 to $0.3 \mathrm{mg} \mathrm{L}^{-1}$ kinetin, 0.1 to $0.5 \mathrm{mg} \mathrm{L}^{-1} 6$-benzyladenine, 0.1 and $0.2 \mathrm{mg} \mathrm{L}^{-1}$ topolin). For each species 5 to 20 media variations were tested. For
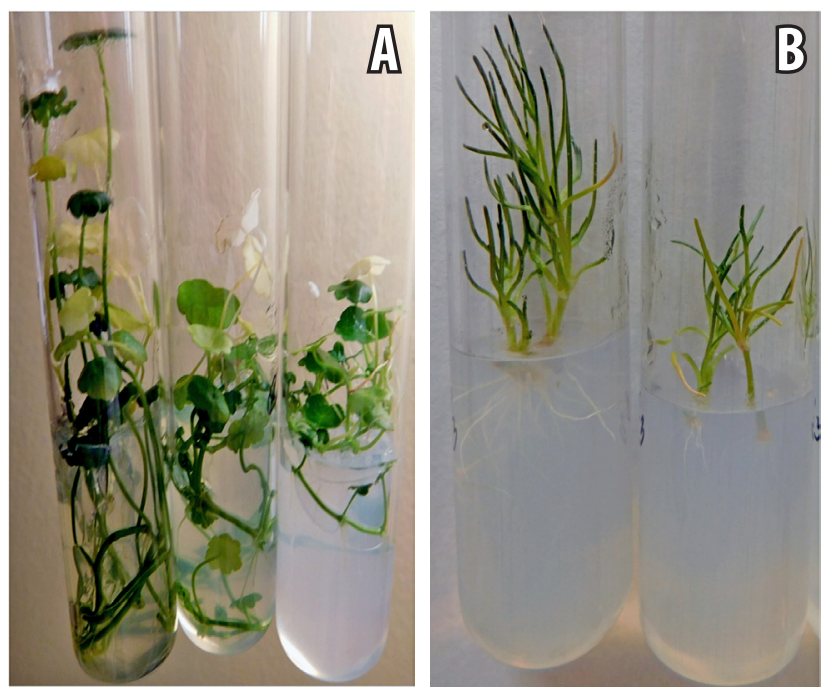

Fig. 1. Cultures of Hydrocotile vulgaris (A) and Spergularia salina (B) after month precondition period at $25^{\circ} \mathrm{C}$ before cold storage on media supplemented with $20 \mathrm{mg} \mathrm{L}^{-1}$ sucrose, sorbitol and mannitol (only for $H$. vulgaris) from the left, respectively. each treatment 15 to 50 explants were used. The cultures were adapted on the media at $25^{\circ} \mathrm{C}$ (photoperiod $16 \mathrm{~h}$, photon flux density of photosynthetically active radiation $40 \mu \mathrm{mol} \mathrm{m} \mathrm{m} \mathrm{s}^{-1}$ ) for four to five weeks. After that, plant growth (rooting, additional shoot number, necrosis, vitrification) was evaluated and cultures were transferred for cold storage at $5{ }^{\circ} \mathrm{C}$ (photoperiod $16 \mathrm{~h}$, photon flux density of photosynthetically active radiation $30 \mu \mathrm{mol}$ $\mathrm{m}^{-2} \mathrm{~s}^{-1}$ ). Cultures were maintained at low temperature for several months up to a few or more years without transfer onto fresh medium. Plant survival was controlled by regrowth of plantlets on fresh MS medium with half reduced nitrate content, with plant agar $6 \mathrm{~g} \mathrm{~L}^{-1}$, $\mathrm{pH} 5.8$, sucrose $2 \%$ in room conditions at $25^{\circ} \mathrm{C}$ (photoperiod $16 \mathrm{~h}$, photon flux density of photosynthetically active radiation $40 \mu \mathrm{mol} \mathrm{m}{ }^{-2}$ $\mathrm{s}^{-1}$ ). After four weeks re-grown plantlets were counted and survival evaluated.

Root structure was analysed to characterize explant growth reaction in relation with various cultivation conditions and species. Root analysis using calibrated scanner STD-1600+ and computer program Win RHIZO 2002 C was conducted for 15 species (shown eight). Total root length of each plant in storage vessel, root surface area and volume, and number of root tips were measured for 5 to 12 plants. Root scanning measured parameters were compared among variants with ANOVA and Tamhane post-hoc test using the SPSS 16 programme (Morgan et al. 2004).

\section{Results}

In standard conditions, plant culture growth was ensured on medium containing $20 \mathrm{~g} \mathrm{~L}^{-1}$ sucrose $20 \mathrm{~g} \mathrm{~L}^{-1}$; in these conditions plant tissues grew rapidly and filled tubes and jars within a few months. To prevent rapid growth, various carbohydrate concentrations and their combinations in media were tested for each species (Table 1). Effect of

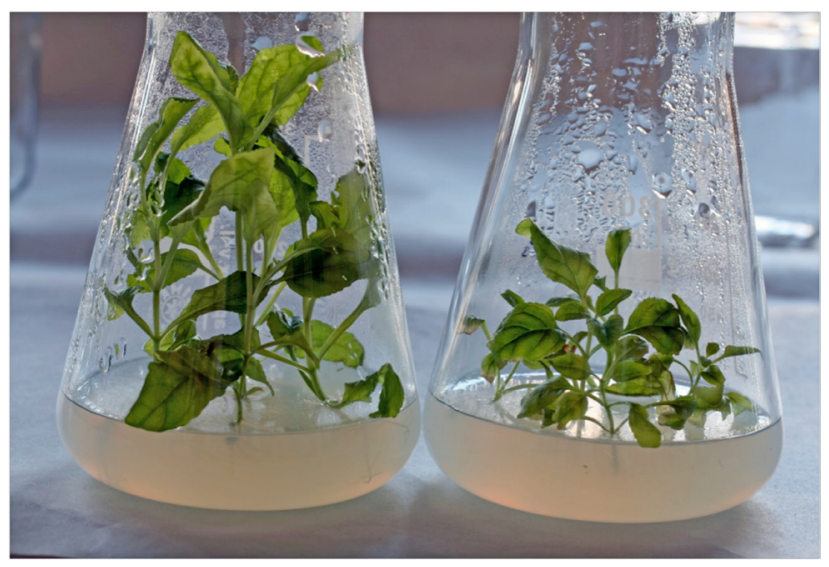

Fig. 2. Cultures of Scrophularia umbrosa after month precondition period at $25^{\circ} \mathrm{C}$ before cold storage on media supplemented with $20 \mathrm{mg} \mathrm{L}^{-1}$ sucrose and sorbitol from the left, respectively. 


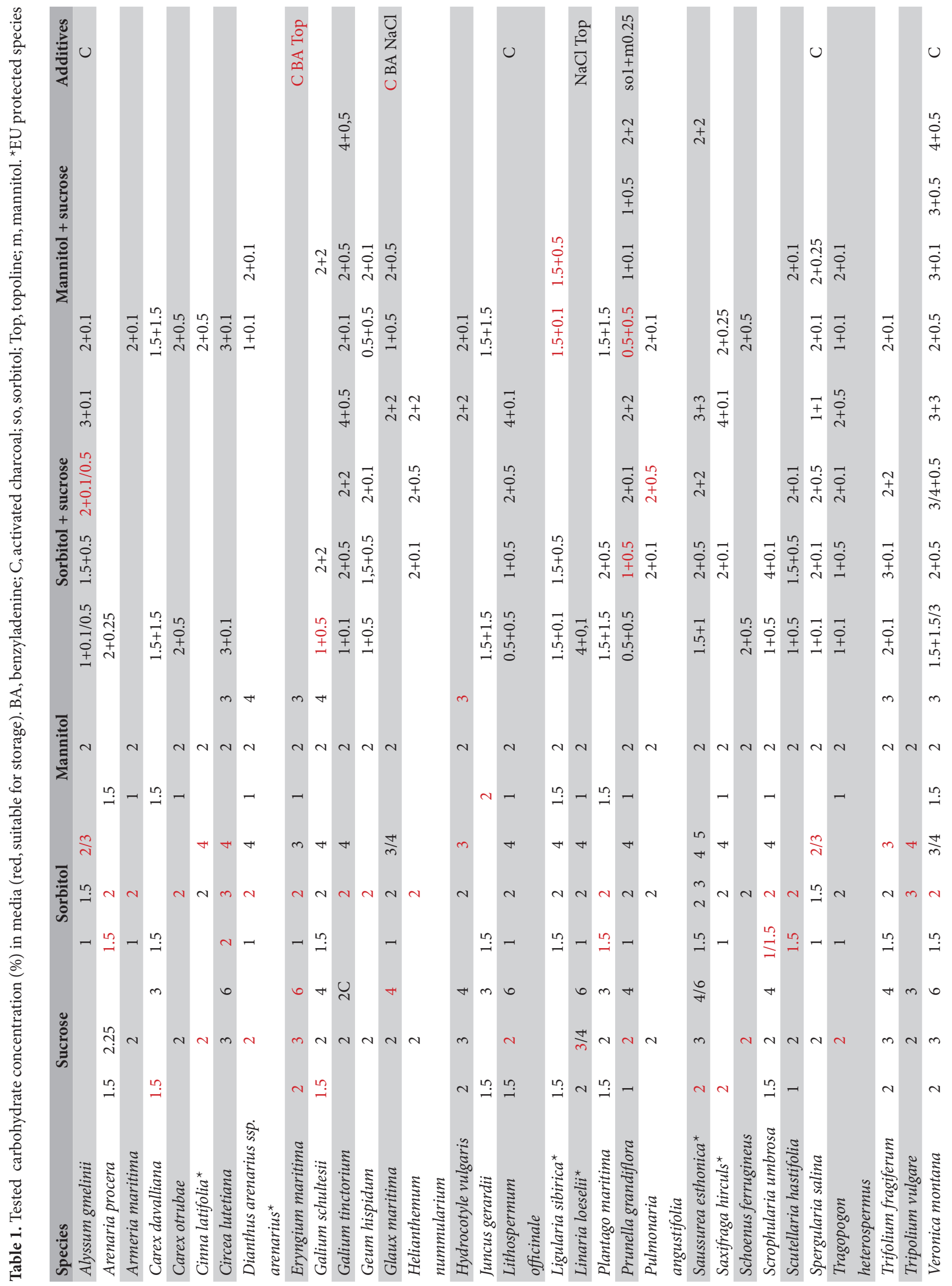



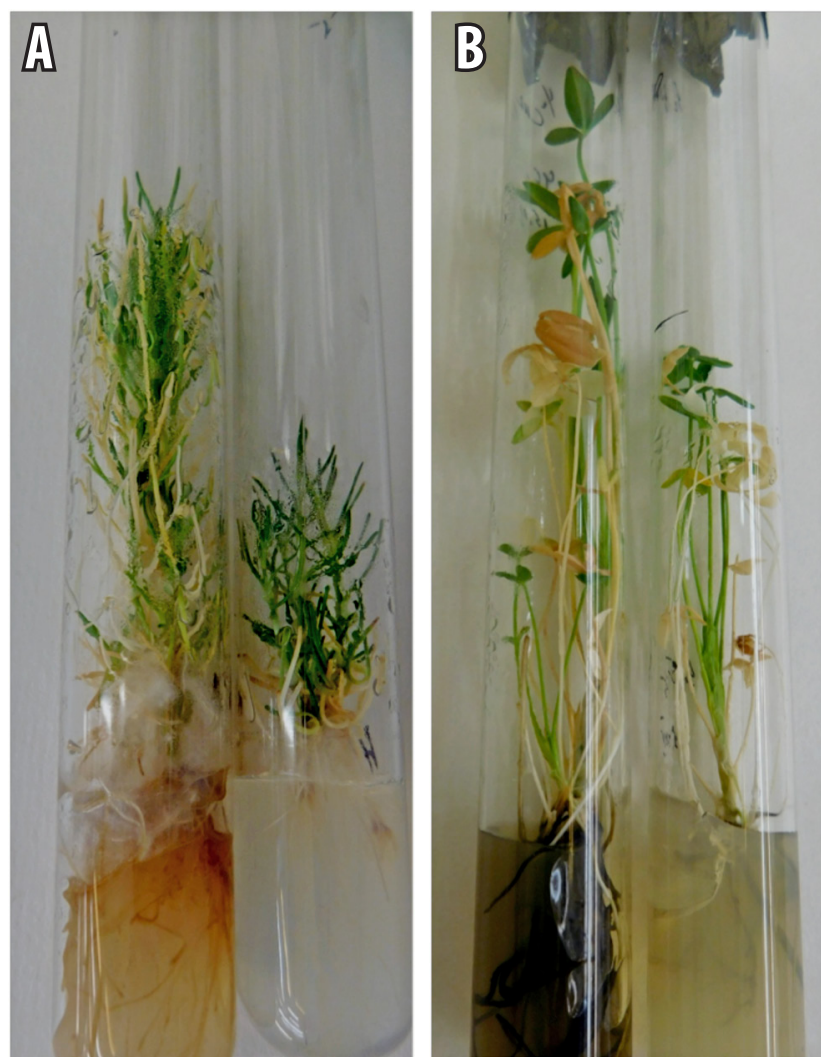

Fig. 3. Cultures of Spergularia salina (A) and Trifolium fragiferum (B) after a year of cold storage on media supplemented with $20 \mathrm{mg}$ $\mathrm{L}^{-1}$ sucrose and sorbitol from the left, respectively.
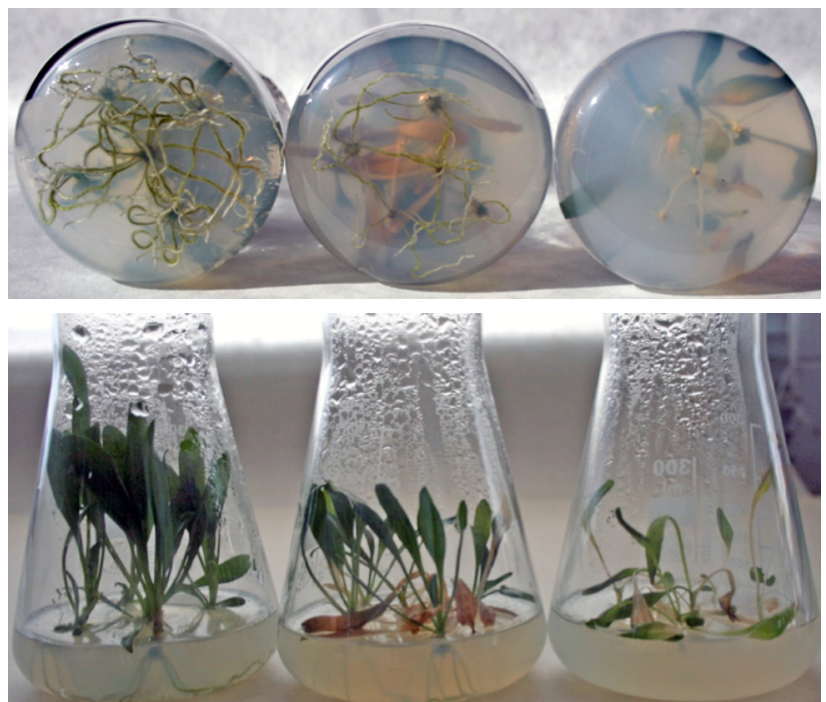

Fig. 4. Cultures of Tripolium vulgare during cold storage (from left) on media supplemented with $20 \mathrm{mg} \mathrm{L}^{-1}$ sucrose, $40 \mathrm{mg} \mathrm{L}^{-1}$ sorbitol and $20 \mathrm{mg} \mathrm{L}^{-1}$ mannitol.

media components on shoot cultures appeared during prestorage culturing under normal temperature conditions (Fig. 1,2) and in many cases a growth retarding effect of polyols was evident (Fig. 3, 4, 5). This allowed to choose more appropriate storage media.

Initial growth-reducing effect of sorbitol and mannitol was tested for long-term storage as well. During prolonged
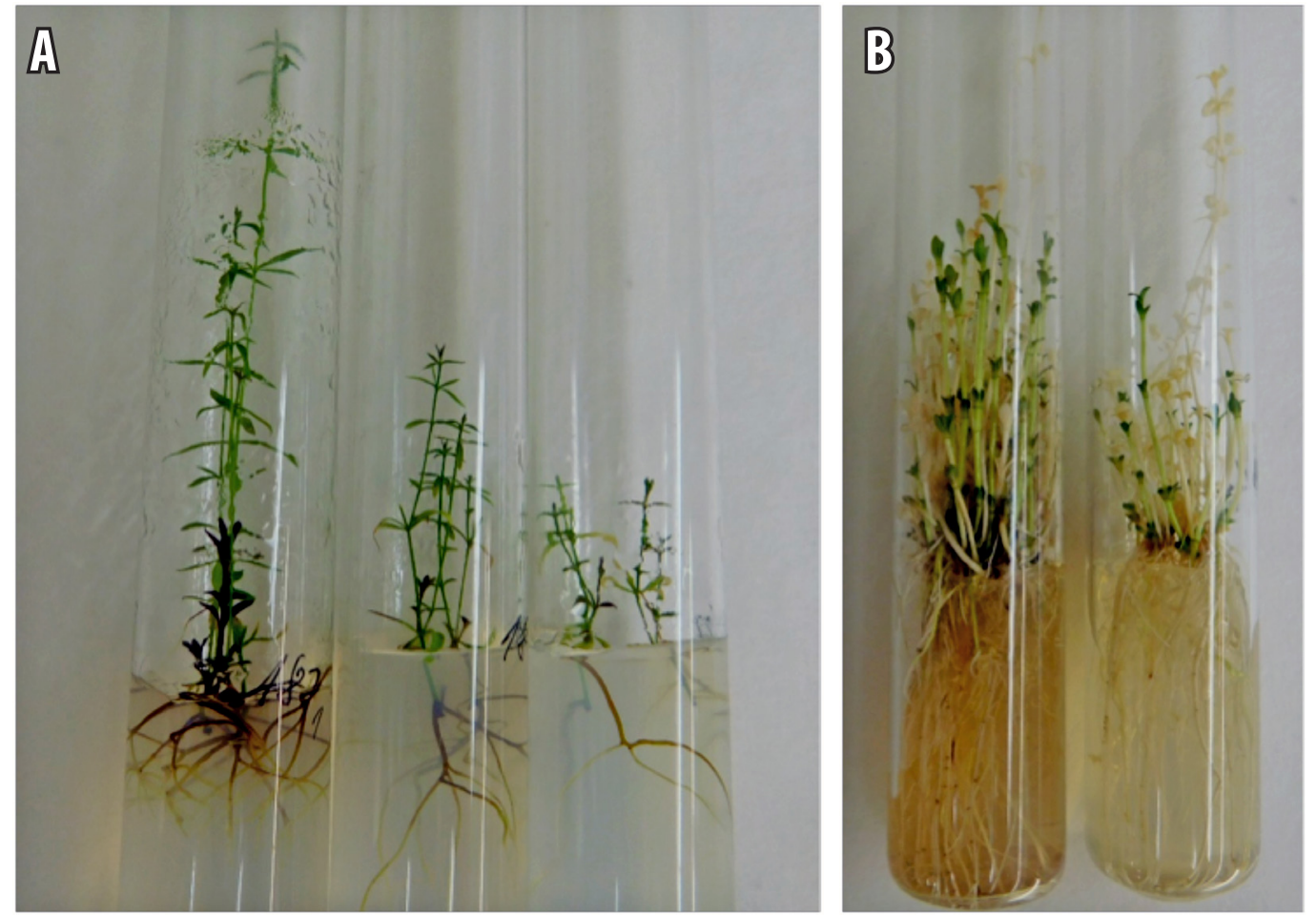

Fig. 5. Cultures of Galium tinctorium (A) after 4 month cold storage (from left) on media supplemented with $30 \mathrm{mg} \mathrm{L^{-1 }}$ sucrose, $30 \mathrm{mg}$ $\mathrm{L}^{-1}$ and $40 \mathrm{mg} \mathrm{L}^{-1}$ sorbitol and Glaux maritima (B) after three years cold storage supplemented with $40 \mathrm{mg} \mathrm{L}^{-1}$ sucrose and $40 \mathrm{mg} \mathrm{L}^{-1}$ sorbitol. 
cultivation some additional effects of polyols on plant growth appeared. Mannitol caused necrosis, vitrification and completely arrested root growth for some species (Galium schultesii, Glaux maritima, Prunella grandiflora, Pulmonaria angustifolia, Saussurea esthonica, Spergularia salina etc., Table 2). The majority of species tested showed successful growth on media with sorbitol (Table 2);

Table 2. Survival time and respnse of rare plant species tested on polyols in media. +, living explants; r, reduced growth; -, unsuitable for growth. ${ }^{\star}$ EU protected species

\begin{tabular}{|c|c|c|c|}
\hline Species & $\begin{array}{c}\text { Storage } \\
\text { time (years) }\end{array}$ & $\begin{array}{l}\text { Response } \\
\text { on sorbitol }\end{array}$ & $\begin{array}{c}\text { Response } \\
\text { on } \\
\text { mannitol }\end{array}$ \\
\hline Alyssum gmelinii & 3 & $+\mathrm{r}$ & $+\mathrm{r}$ \\
\hline Angelica palustris & 1 & + & $+/-$ \\
\hline Arenaria procera & 5 & + & $+\mathrm{r}$ \\
\hline Armeria maritima & 3 & $+\mathrm{r}$ & $+\mathrm{r} /-$ \\
\hline Carex davalliana & 3 & - & - \\
\hline Carex otrubae & $>2$ & $+\mathrm{r}$ & $+\mathrm{r} /-$ \\
\hline Cinna latifolia* & 1 & + & $+\mathrm{r}$ \\
\hline Circea lutetiana & 1 & $+\mathrm{r}$ & $+\mathrm{r} /-$ \\
\hline $\begin{array}{l}\text { Dianthus arenarius } \\
\text { ssp. arenarius* }\end{array}$ & 3 & $+r$ & $+\mathrm{r}$ \\
\hline Eryngium maritima & 2 & $+\mathrm{r}$ & $+\mathrm{r}$ \\
\hline Galium schultesii & 3 & $+r$ & - \\
\hline Galium tinctorium & 4 & $+r$ & $+\mathrm{r} /-$ \\
\hline Geum hispidum & $>1$ & $+r$ & $+\mathrm{r} /-$ \\
\hline Glaux maritima & 3 & $+\mathrm{r}$ & - \\
\hline $\begin{array}{l}\text { Helianthemum } \\
\text { nummularium }\end{array}$ & 4 & $+r$ & \\
\hline Hydrocotyle vulgaris & 8 & $+r$ & $+\mathrm{r}$ \\
\hline Juncus gerardii & 4 & + & $+\mathrm{r}$ \\
\hline $\begin{array}{l}\text { Lithospermum } \\
\text { officinale }\end{array}$ & 1 & $+\mathrm{r} /-$ & - \\
\hline Ligularia sibirica* & 3 & $+r$ & $+\mathrm{r}$ \\
\hline Linaria loeselii* & $3-5$ & $+\mathrm{r}$ & $+r$ \\
\hline Plantago maritima & 3 & $+\mathrm{r}$ & $+\mathrm{r} /-$ \\
\hline Prunella grandiflora & 3 & $+\mathrm{r}$ & $+\mathrm{r} /-$ \\
\hline $\begin{array}{l}\text { Pulmonaria } \\
\text { angustifolia }\end{array}$ & 2 & $+\mathrm{r}$ & $+\mathrm{r} /-$ \\
\hline Saussurea esthonica* & 1 & - & - \\
\hline $\begin{array}{l}\text { Schoenus } \\
\text { ferrugineus }\end{array}$ & 2 & $+r$ & $+\mathrm{r}-$ \\
\hline $\begin{array}{l}\text { Scrophularia } \\
\text { umbrosa }\end{array}$ & 5 & $+r$ & $+r$ \\
\hline Scutellaria hastifolia & $>2$ & $+r$ & $+/-$ \\
\hline Spergularia salina & 3 & $+r$ & - \\
\hline $\begin{array}{l}\text { Tragopogon } \\
\text { heterospermus }\end{array}$ & $>1$ & + & - \\
\hline Trifolium fragiferum & 5 & $+\mathrm{r}$ & $+\mathrm{r} / ?$ \\
\hline Tripolium vulgare & 5 & $+\mathrm{r}$ & $+r$ \\
\hline Veronica montana & 3 & $+\mathrm{r}$ & + \\
\hline
\end{tabular}

nevertheless, there were some exceptions, as Lithospermum officinale and Carex davalliana. The precondition period of Carex davalliana was successful on six media (Table 1 , Fig. 6) and there was limited growth of shoot and especially root number with sorbitol and mannitol (in comparison with sucrose). After a nine-month storage period plants on media with both polyols and their combinations with sucrose became necrotic and seemed to be unsuitable for growth of this species during a longer storage period. This might be explained by weak root development on media with polyols: plants on sucrose media had well branched roots, but those on media with polyols were without branching.

During four years of storage Carex davalliana remined vital only on media with sucrose. Similar results in respect to polyols were obtained with Saussurea esthonica, but storage time of its cultures was shorter, about one year. For storage of Saussurea esthonica and Eryngium maritimum, new shoot formation was essential and therefore cytokinins were required. Topoline $0.1 \mathrm{mg} \mathrm{L}^{-1}$ and benzyladenine (BA) 0.1 and $0.3 \mathrm{mg} \mathrm{L}^{-1}$ were used for Eryngium maritimum. These additives promoted new shoot production; the best media were with sucrose $30 \mathrm{~g} \mathrm{~L}^{-1}+$ topoline or BA $0.1 \mathrm{mg}$ $\mathrm{L}^{-1}$.

Differences observed among species corresponded to their sensitivity to osmolytes in media. Retarded growth and good vitality were observed for Armeria maritima, Pulmonaria angustifolia, Scrophularia umbrosa, Spergularia salina (Fig 3, 2), Tripolium vulgare with sorbitol $20 \mathrm{~g} \mathrm{~L}^{-1}$, Galium tinctorium with sorbitol $20 \mathrm{~g} \mathrm{~L}^{-1}$ and $40 \mathrm{~g} \mathrm{~L}^{-1}$, and Dianthus arenarius (Table 3) with mannitol $20 \mathrm{~g} \mathrm{~L}^{-1}$. Results with Veronica montana and Scutellaria hastifolia showed large species plasticity: their growth was similar on seven media with sucrose, sorbitol, mannitol or combinations of these substances. Shoot growth of Veronica montana was slightly retarded only on media containing sorbitol while rooting did not differ significantly (Fig 7). Gallium schultesii, in contrary, was very sensitive to media composition: it accumulated anthocyans (maximum on sucrose $40 \mathrm{mg}$

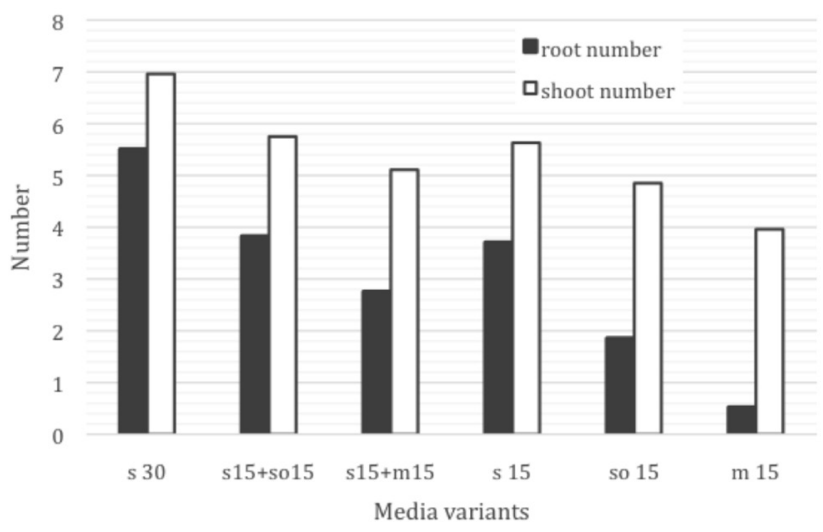

Fig. 6. Effect of different media on Carex davalliana growth after precondition period one month. s, sucrose; so, sorbitol; m, mannitol. Numbers indicate concentration $\left(\mathrm{mg} \mathrm{L}^{-1}\right)$. 
Table 3. Effect of different media on root morphology (mean \pm SE) of rare plants during slow growth storage in vitro. s, sucrose; so, sorbitol; BA, benzyladenine; kin, kinetin; C, activated charcoal. Different letters indicate significant differences between treatments for a particular species $(p<0.05)$

\begin{tabular}{|c|c|c|c|c|}
\hline Species & Media & Root length $(\mathrm{cm})$ & Surface area $(\mathrm{cm} 2)$ & Root tips (number) \\
\hline \multirow[t]{7}{*}{ Dianthus arenarius } & s 20 & $54.8 \pm 3.2 \mathrm{a}$ & $3.9 \pm 0.4 \mathrm{~b}$ & $240 \pm 32 \mathrm{a}$ \\
\hline & s 20C & $114.2 \pm 13.3 \mathrm{a}$ & $7.2 \pm 1.0 \mathrm{~b}$ & $771 \pm 104 c$ \\
\hline & s $20+$ so 20 & $49.6 \pm 3.9 \mathrm{a}$ & $3.3 \pm 0.3 b$ & $138 \pm 21 \mathrm{ac}$ \\
\hline & s 40 & $59.0 \pm 5.5 \mathrm{a}$ & $4.1 \pm 0.4 \mathrm{~b}$ & $123 \pm 12 \mathrm{ab}$ \\
\hline & so 20 & $26.2 \pm 3.5 b$ & $1.8 \pm 0.3 \mathrm{ab}$ & $110 \pm 20 b$ \\
\hline & so 40 & $21.7 \pm 1.8 b$ & $1.7 \pm 0.2 \mathrm{ab}$ & $103 \pm 13 b$ \\
\hline & $\mathrm{m} 20$ & $22.7 \pm 5.0 b$ & $1.6 \pm 0.3 \mathrm{a}$ & $82 \pm 22 b$ \\
\hline \multirow[t]{4}{*}{ Glaux maritima } & s 30 & $9.2 \pm 0.8 \mathrm{a}$ & $0.6 \pm 0.1 \mathrm{a}$ & $17 \pm 1 \mathrm{a}$ \\
\hline & s $30 \mathrm{C}$ & $9.1 \pm 0.8 \mathrm{a}$ & $0.6 \pm 0.1 \mathrm{a}$ & $19 \pm 3 a$ \\
\hline & s $30 \mathrm{NaCl} 100$ & $8.1 \pm 1.1 \mathrm{a}$ & $0.5 \pm 0.1 \mathrm{a}$ & $17 \pm 3 a$ \\
\hline & so 30 & $7.3 \pm 0.8 \mathrm{a}$ & $0.5 \pm 0.1 \mathrm{a}$ & $17 \pm 3 a$ \\
\hline Helianthemum & s 20 & $69.9 \pm 8.4 \mathrm{a}$ & $6.6 \pm 0.8 \mathrm{a}$ & $135 \pm 18 \mathrm{a}$ \\
\hline \multirow[t]{3}{*}{ nummularium } & so 20 & $19.3 \pm 2.3 b$ & $2.0 \pm 0.3 \mathrm{~b}$ & $40 \pm 6 b$ \\
\hline & so $20+$ s 5 & $118.7 \pm 11.4 \mathrm{c}$ & $9.6 \pm 0.8 \mathrm{c}$ & $161 \pm 14 a$ \\
\hline & s $20+$ so 20 & $111.1 \pm 22.4 c$ & $11.1 \pm 2.2 c$ & $153 \pm 30 a$ \\
\hline \multirow[t]{7}{*}{ Pulmonaria angustifolia } & s 20 & $112.4 \pm 14.7 \mathrm{~cd}$ & $33.3 \pm 4.8 \mathrm{ac}$ & $902 \pm 125 \mathrm{a}$ \\
\hline & s $20 \mathrm{BA}$ & $81.0 \pm 13.0 \mathrm{c}$ & $26.3 \pm 4.9 \mathrm{a}$ & $754 \pm 107 a$ \\
\hline & s 40 & $124.0 \pm 9.6 \mathrm{~d}$ & $38.9 \pm 2.6 c$ & $927 \pm 83 \mathrm{a}$ \\
\hline & s $20+$ so 20 & $117.0 \pm 18.9 \mathrm{~cd}$ & $33.6 \pm 5.0 \mathrm{ac}$ & $727 \pm 125 \mathrm{a}$ \\
\hline & s $20+$ so $20 \mathrm{C}$ & $130.0 \pm 25.2 \mathrm{~cd}$ & $27.7 \pm 5.4 \mathrm{ac}$ & $443 \pm 134 b$ \\
\hline & so 20 & $13.3 \pm 3.3 b$ & $3.3 \pm 0.8 b$ & $43 \pm 13 c$ \\
\hline & so 40 & $2.8 \pm 0.5 \mathrm{a}$ & $0.9 \pm 0.1 \mathrm{~b}$ & $11 \pm 3 c$ \\
\hline \multirow[t]{10}{*}{ Saussurea esthonica } & s 30 & $22.4 \pm 3.5 \mathrm{~b}$ & $4.3 \pm 0.6 b$ & $15 \pm 2 b$ \\
\hline & s $30 \mathrm{BA}$ & $8.4 \pm 3.8 \mathrm{bc}$ & $1.5 \pm 0.6 \mathrm{~b}$ & $7 \pm 3 b$ \\
\hline & s 50 & $43.1 \pm 6.4 \mathrm{a}$ & $8.2 \pm 1.2 \mathrm{a}$ & $26 \pm 4 a$ \\
\hline & s $50 \mathrm{BA}$ & $17.4 \pm 4.2 \mathrm{bc}$ & $3.2 \pm 0.8 \mathrm{~b}$ & $10 \pm 2 b$ \\
\hline & s $30+$ so 20 & $33.7 \pm 7.5 \mathrm{a}$ & $6.0 \pm 1.2 \mathrm{ab}$ & $19 \pm 3 b$ \\
\hline & s30 + so $30 \mathrm{BA}$ & $30.7 \pm 8.2 \mathrm{a}$ & $6.2 \pm 1.7 \mathrm{ab}$ & $18 \pm 5 b$ \\
\hline & so 30 & $7.1 \pm 1.0 \mathrm{~b}$ & $1.7 \pm 0.3 \mathrm{~b}$ & $6 \pm 2 b$ \\
\hline & so $30 \mathrm{BA}$ & $12.0 \pm 6.4 \mathrm{bc}$ & $2.1 \pm 1.1 \mathrm{~b}$ & $13 \pm 5.9 \mathrm{~b}$ \\
\hline & so 50 & $9.4 \pm 1.6 c$ & $2.3 \pm 0.4 \mathrm{~b}$ & $9 \pm 1 b$ \\
\hline & so $50 \mathrm{BA}$ & $19.3 \pm 11.0 \mathrm{bc}$ & $4.2 \pm 2.3 \mathrm{~b}$ & $23 \pm 11 \mathrm{ab}$ \\
\hline \multirow[t]{5}{*}{ Trifolium fragiferum } & s 30 & $82.8 \pm 10.7 \mathrm{a}$ & $7.9 \pm 1.1 \mathrm{a}$ & $158 \pm 54 \mathrm{a}$ \\
\hline & s $30 \mathrm{C}$ & $52.3 \pm 9.3 \mathrm{a}$ & $5.3 \pm 1.1 \mathrm{ab}$ & $137 \pm 23 \mathrm{a}$ \\
\hline & s $30 \mathrm{C} \mathrm{BA}$ & $47.4 \pm 4.4 \mathrm{a}$ & $4.7 \pm 0.6 \mathrm{ab}$ & $123 \pm 25 \mathrm{a}$ \\
\hline & s $30 \mathrm{NaCl} 100$ & $34.7 \pm 12.9 \mathrm{a}$ & $4.2 \pm 1.6 \mathrm{ab}$ & $62 \pm 20 a$ \\
\hline & so 30 & $31.1 \pm 7.6$ & $2.3 \pm 0.6 b$ & $73 \pm 20 a$ \\
\hline \multirow[t]{4}{*}{ Tripolium vulgare } & s 20 & $204.4 \pm 37.9 \mathrm{a}$ & $52.6 \pm 9.0 \mathrm{a}$ & $1154 \pm 295 \mathrm{a}$ \\
\hline & so 20 & $34.0 \pm 7.1 \mathrm{~b}$ & $6.5 \pm 1.6 \mathrm{~b}$ & $119.6 \pm 34 b$ \\
\hline & so 30 & $26.0 \pm 3.9 b$ & $5.0 \pm 1.0 \mathrm{~b}$ & $27 \pm 6 c$ \\
\hline & so 40 & $17.7 \pm 6.1 b$ & $3.0 \pm 1.2 \mathrm{~b}$ & $15 \pm 5 \mathrm{cb}$ \\
\hline \multirow[t]{7}{*}{ Veronica montana } & s 30 & $14.7 \pm 2.1 \mathrm{a}$ & $1.1 \pm 0.1 \mathrm{ab}$ & $34 \pm 4 \mathrm{a}$ \\
\hline & s 30 kin & $20.6 \pm 3.4 \mathrm{ab}$ & $1.4 \pm 0.2 \mathrm{ab}$ & $44 \pm 9 \mathrm{ab}$ \\
\hline & s 30 C kin & $14.5 \pm 2.9 \mathrm{a}$ & $1.0 \pm 0.2 \mathrm{a}$ & $36 \pm 5 a$ \\
\hline & s $30+$ so 15 & $21.3 \pm 1.8 \mathrm{ab}$ & $1.7 \pm 0.1 \mathrm{~b}$ & $37 \pm 3 a$ \\
\hline & s $30+$ so 30 & $33.1 \pm 3.1 b$ & $2.8 \pm 0.3 \mathrm{~b}$ & $54 \pm 6 b$ \\
\hline & s 60 & $35.2 \pm 4.6 b$ & $2.6 \pm 0.4 \mathrm{ab}$ & $56 \pm 10 b$ \\
\hline & so 30 & $19.2 \pm 2.4 \mathrm{ab}$ & $1.6 \pm 0.2 \mathrm{ab}$ & $30 \pm 4 \mathrm{a}$ \\
\hline
\end{tabular}


$\mathrm{L}^{-1}$ ) and had necrotic apices and leaves. After few months of cold storage greener shoots occured on medium with sucrose $20 \mathrm{~g} \mathrm{~L}^{-1}+\mathrm{BA} 0.2 \mathrm{mg} \mathrm{L}^{-1}$.

Root growth on media with various ingredients is shown in Table 3. Among media tested, root growth on medium with sucrose and sorbitol differed significantly in most of cases (except for Glaux maritima and Veronica montana). The root surface area of Trifolium fragiferum was significantly larger in treatments with sucrose in comparison with sorbitol (activated charcoal and $\mathrm{NaCl}$ additives gave intermediate results, Table 3 ).

It was observed that after 10-month cold storage, for example, root length of Pulmonaria angustifolia with $2 \%$ sorbitol was tenfold less in comparison to $2 \%$ sucrose in medium ( $13 \pm 3$ and $112 \pm 15 \mathrm{~cm}$, respectively). Root structure analysis revealed two more suitable indices: root length and number of root tips; surface area and root volume showed the same tendencies. Root length and surface area of Tripolium vulgare on media with sorbitol were significantly smaller than on media with sucrose (Table 3). In the case of Dianthus arenarius, activated charcoal stimulated root growth (root length, number of root tips, root volume); $2 / 3$ of roots were very small. Sorbitol and mannitol decreased these root parameters and also number of additional shoots.

Basic reactions of rare plant species tested on media with osmolytes under germplasm bank conditions are shown in Table 2. Plantlets maintained vitality at low growth rate without subcultures one year for species Cinna latifolia, Lithospermum officinale, and Saussurea esthonica, two years for Pulmonaria angustifolia (Fig. 8), three years for Dianthus arenarius, Glaux maritima, Gallium schultesii, Plantago maritima, and Spergularia salina and more years for Arenaria procera, Galium tinctorium, Hydrocotile vulgaris, Scrophularia umbrosa, and Trifolium fragiferum. Eryngium maritimum could be stored at $5{ }^{\circ} \mathrm{C}$ about two years due to additional shoot formation during storage.

Survival and regrowth capacity were estimated after storage (Table 2). Survival differed considerably between

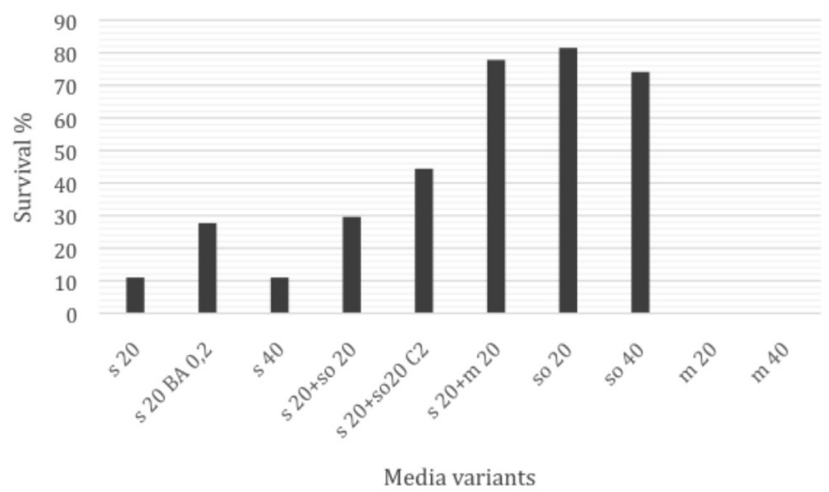

Fig. 8. Survival (\%) of Pulmonaria angustifolia after two-year storage at $5{ }^{\circ} \mathrm{C}$. s, sucrose; so, sorbitol; m, mannitol. Numbers indicate concentration $\left(\mathrm{mg} \mathrm{L}^{-1}\right)$.
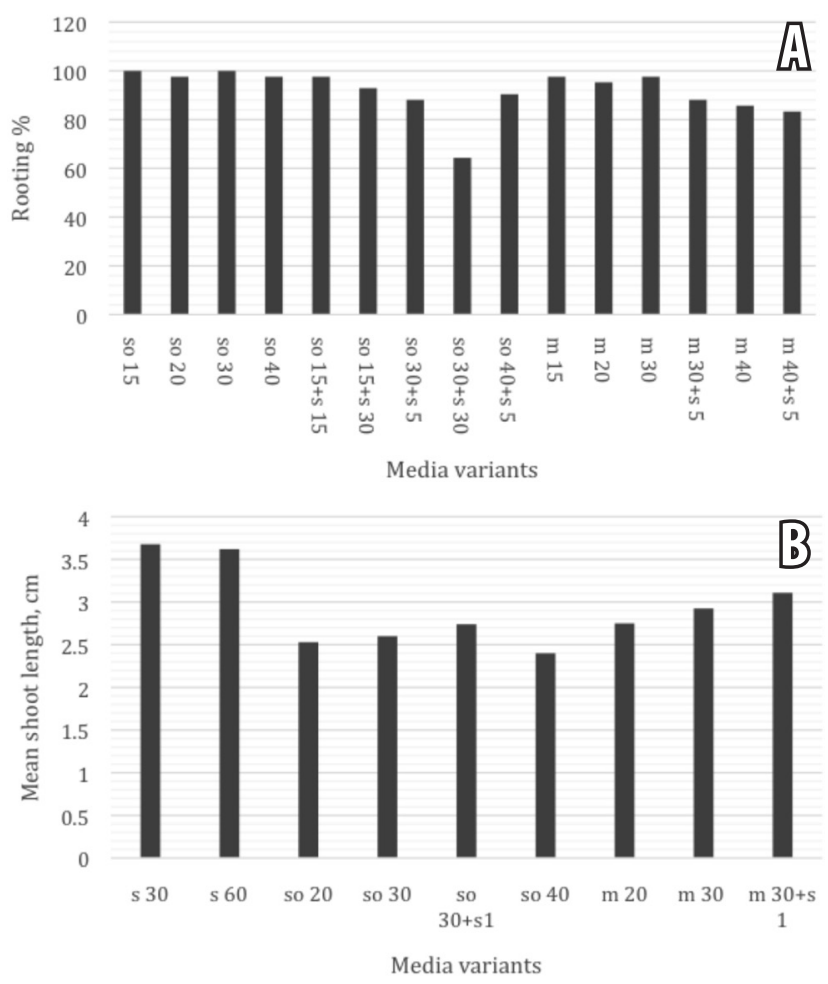

Fig. 7. Effect of different media on Veronica montana rooting (A) and shoot length in the other experiment with $100 \%$ rooting (B) after adaptation period. s, sucrose; so, sorbitol; m, mannitol. Numbers indicate concentration $\left(\mathrm{mg} \mathrm{L}^{-1}\right)$.

media used, for example Plantago maritima in vitro cultures could be stored better on media with sorbitol than on sucrose or mannitol (Fig. 9). Successful regrowth was obtained for all species and growth parameters were estimated for five of these species. Recovery of species from slow growth storage depended on effect of storage medium on subsequent growth in normal conditions. Shoot multiplication was reduced in cases when the previous medium retarded growth. For instance, media with activated charcoal, BA, sorbitol or proline reduced growth and shoot production during cold storage of Glaux maritima. The same tendency remained after storage during the first subculture in normal conditions (Fig. 10). Effect of storage medium on shoot

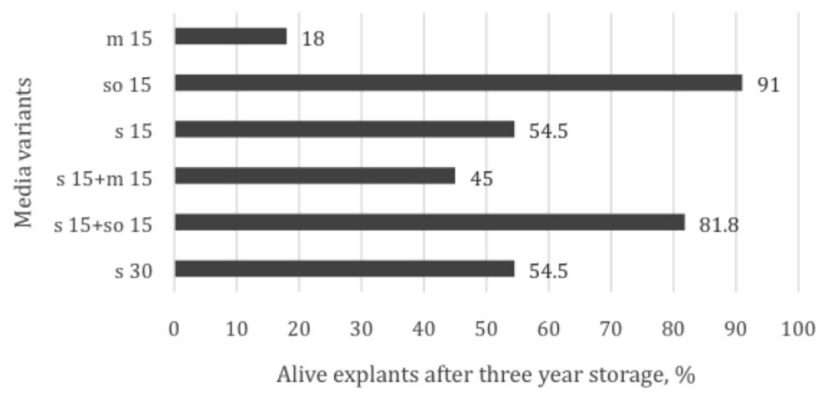

Fig. 9. Plantago maritima living explants after three-year storage at $5{ }^{\circ} \mathrm{C}$ temperature on media with sucrose (s), sorbitol (so), mannitol (m) and their combinations. 

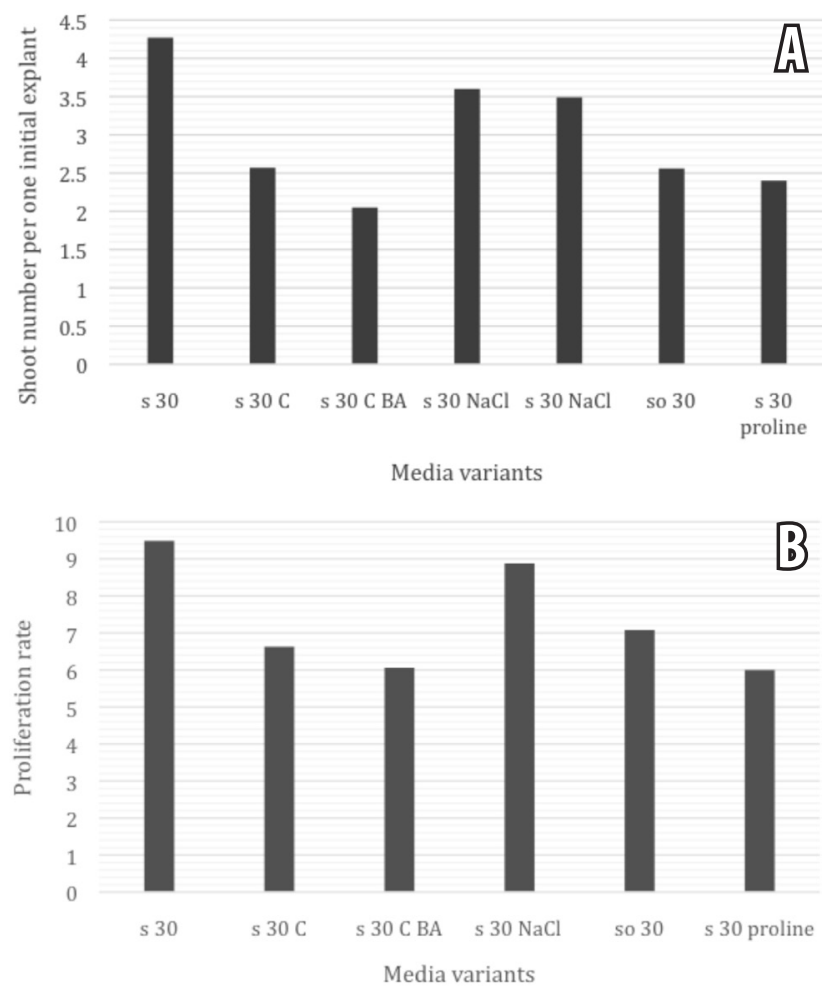

Fig. 10. Influence of cold storage medium on shoot growth of Glaux maritima during storage (A) and after storage on MS medium with sucrose $20 \mathrm{~g} \mathrm{~L}^{-1}$ (B). s, sucrose; so, sorbitol; m, mannitol. Numbers indicate concentration $\left(\mathrm{mg} \mathrm{L}^{-1}\right)$.

growth after storage was observed. All cultures retained regrowth capacity after storage.

\section{Discussion}

Possible tools for conserving in vitro cultures of rare plants and reducing supplementary handling of the in vitro preserved material were developed. Media modifications by using sorbitol and mannitol are useful for medium and long-term cold storage of threatened species. Development of process for rare species storage at low temperature at slow growth conditions has started quite recently (Holobiuc et al. 2008; Mitoi et al. 2009). These methods have been previously widely used commercially for plant cold storage in in vitro (Bertrand-Desbrunais et al. 1992; Fletcher 1994; Negash et al. 2001; Pereira et al. 2003; Lambardi et al. 2006; Capuana, Ponti 2008; Joshi, Jadhav 2013). It was found that species with easy cultivation in tissue culture in experiments at growth-limiting conditions were able to adapt for growth on media with osmolytes (sorbitol, mannitol). For instance, Lipavska and Vreugdenhil (1996) found a dramatic decrease in dry matter at higher concentrations of mannitol. Growth retarding effect of these osmolytes in appropriate concentrations coincided with results of our experiments (Fig. 1 to 5, Table 3). Plant cell division is inhibited by osmolytes introduced into cultivation media and, consequently, plant growth is reduced (Xiong, Zhu 2002). Therefore, in many cases with polyols, we obtained smaller plants during the precondition period. Estimated reaction of 47 species was quite different on cultivation in media with polyols as the only carbon sources, as cold storage under the studied experimental conditions was suitable for 32 species for medium or longer storage period (Table 2).

Carbohydrates have two main roles: (i) a carbon and energy source and (ii) an osmotic agent. Those sugars that are not metabolized can be used to alter the osmotic conditions in the tissue, which also seems to influence adventitious shoot and root formation (Welander, Pawlicki 1994). In addition to essential roles as substrates in carbon and energy metabolism and in polymer biosynthesis, sugars have important hormone-like functions as primary messengers in signal transduction (Rolland et al. 2002). Other studies indicate positive effect by radical scavenging of sorbitol and mannitol in plant storage and life processes (Cassels, Curry 2001; Molassiotis et al. 2006, Mitoi et al. 2009) and of carbon transport compounds in the phloem (Gaspar et al. 2002). A physiological role of polyols as agents of translocation and endogenous osmoregulation has been considered, together with more biochemical aspects of their utility as reserve carbohydrates, as sinks for photosynthetically produced reducing compounds and for co-enzyme regulation (Lewis, Smith 1967; Mioti et al. 2009). For germplasm preservation, media with sorbitol or mannitol have been widely used and shown to maintain cultures viable at low growth rate without subcultures for four or six months or more (Negash et al. 2001; Hao, Deng 2003, Pereira et al. 2003; Mitoi et al. 2009). Our study implemented a longer storage time, and showed that at least cultures of 27 species can be stored for more than year (Table 2).

Slow growth during in vitro cultivation generally is explained by low photosynthetic ability, as photosynthetic rate is restricted by low $\mathrm{CO}_{2}$ concentration during the light period. High amounts of reserve saccharides are more important for plant survival than full autotrophy (Voračkova et al. 1998). Therefore, elevated concentration of sucrose in cultivation medium is needed for plant survival in unsuitable conditions like cold growth storage (Kḷvina, Ievinsh 2008) and saccharide supplement in cultivation media is important. Heterotrophic cultures can adjust their metabolism from consumption of saccharides to consumption of polyols as an alternative carbon-energy source when the medium is sucrose-deficient (Steinitz 1999). However, ability to change metabolism or grow on media with polyols differs between species. In the present study, Carex davaliana, Eryngium maritima, Saussurea esthonica could be preserved only on medium with sucrose. On the other hand, some polyols are characteristic for particular families, e.g., sorbitol in Rosaceae (Lewis, Smith 1967) or higher taxonomic units, as mannitol is the most common 
form of polyols in Angiosperms. In our experiments, more species were successfully preserved on media with sorbitol (24) than with mannitol (11).

When explants are exposed to low temperature, the level of reactive oxygen species increases (El-Sheekh, Rady 1995). Oxygen toxicity during cold storage can be reduced by plant endogenous mechanisms, such as peroxide metabolism enzymes as well as media components with antioxidant features. Both osmotic and saline media significantly increased non-enzymatic antioxidant activity (Molassiotis et al. 2006). Mannitol and sorbitol act also as osmoprotectants and quenchers of reactive oxygen species (Jennings et al. 1998). Perhaps the successful long term preservation success of some species in our experiments was due to this additional function of used polyols. Inclusion osmolytes in culture media causes morphological changes, e.g. inhibition of shoot growth (Xiong, Zhu 2002). This was confirmed for numerous wild plants, for example, Pulmonaria angustifolia (Fig. 9); maintaining on medium with sorbitol was more successful than for that with sucrose or mannitol, due to slower shoot growth and ability to form roots.

Storage of cultures at $5{ }^{\circ} \mathrm{C}$ on appropriate medium appears to be a promising technique for maintenance and medium-term conservation of rare species with economy of labour and materials for transfer. Species can be coldstored from six months up to a few years or more. Survival rate during storage was influenced by media and genotype. Sorbitol and mannitol were appropriate growth retarding substances for cold storage of rare species, only their concentration and combinations with other compounds must be specified for each species to achieve successful regeneration capacity. In vitro culturing for an extended period under slow growth conditions (1 to 8 years) may allow storage of rare species germplasm and utilization of stored material when needed for National Botanic garden expositions, experimental purposes or reintroduction.

\section{Acknowledgements}

The present work was developed in the framework of the projects of Fund for Environmental Protection of Latvia during 2005 2016. The study was financially supported also by the National Research Programme „EVIDEnT” 2014-2017 (Agreement No. 10-4/VPP-2/19).

\section{References}

Ankita P., Animesh S. 2013. Effects of mannitol, sorbitol and sucrose on growth inhibition and in vitro conservation of germplasm of Asparagus racemosus - an important medical plant. Int. J. Phytomed. Rel. Industr. 5: 71-74.

Bertrand-Desbrunais A., Noirot M., Charrier A. 1992. Slow growth in vitro cultivation of coffee (Coffea spp.). Plant Cell Tissue Organ Cult. 31: 105-110.

Bramwell D. 1990. The role of in vitro cultivation in the conservationof endangered species. In: Hernandez Bermejo
J.E., Clemente M., Heywood V. (eds) Conservation Techniques in Botanic Gardens. Koeltz Scientific Books, pp. 3-15.

Capuana M., Ponti F. 2008. In vitro medium term conservation of Myrtus communis L. Propag. Ornam. Plants 8: 111-113.

Cassells A.C., Curry R.F. 2001. Oxidative stress and physiological, epigenetic and genetic variability in plant tissue culture: implications for micropropagators and genetic engineers. Plant Cell Tissue Organ Cult. 64: 145-157.

Charoensub R., Phansiri S. 2004. In vitro conservation of rose coloured leadwort: Effect of mannitol on growth of plantlets. Kasetsart J. Nat. Sci. 38: 97-102.

El-Sheekh M.M., Rady A.A. 1995. Temperature shift-induced changes in the antioxidant enzyme systemof cyanobacterium Synechocystis PCC 6803. Biol. Plant. 37: 21-25.

Fletcher P. J. 1994. In vitro long-term storage of asparagus. New Zealand J. Crop Hortic. Sci. 22: 351-359.

Gaspar T., Franck T., Bisbis B., Kevers C., Jouve L., Hausman J.F., Dommes J. 2002. Concepts in plant stress physiology. Application to plant tissue cultures. Plant Growth Reg. 37: 263-285.

Ghahery M., Kahrizi D., Bahrami G. 2015. Effect of mannitol on some morphological characteristics of in vitro Stevia rebaudiana Bertoni. Biharean Biol. 11: 94-97.

Hao Y.-J., Deng X.-X. 2003. Genetically stable regeneration of apple plants from slow growth. Plant Cell Tissue Organ Cult. 72: 253-260.

Holobiuc I., Blîndu R., Carasan M., Helepciuc F., Voichiță C., Negrean G. 2008. In vitro conservation strategy in Veronica multifidi ssp. capsellicarpa (Dubovik) A. Jelen. Rom. J. Biol. Plant Biol. 53: 71-81.

Joshi V., Jadhav S.K. 2013. Effect of temperature and media supplements on slow growth conservation of medical plant Spilanthes acmella. Bot. Serb. 37: 155-160.

Jennings D.B., Ehrenshaft M., Pharr D. M, Williamson J. D. 1998. Roles for mannitol and mannitol dehydrogenase in active oxygen-mediated plant defense. Proc. Natl. Acad. Sci. USA 95: 15129-15133.

Kḷaviņa D., Gailīte A., Jakobsone G., N̦ečajeva J., Gavrilova G̦. 2004. Tissue culture technology in conservation of threatened plant species of Latvia. Acta Univ. Latv. 676: 183-188.

Kḷaviņa D., Gailite A., Ievinsh G. 2006. Initial responses of explants from rare and endangered costal plant species during initiation of tissue culture. Acta Univ. Latv. 710: 81-91.

Kḷaviņa D., Ievinsh G. 2008. Growth of tissue culture and changes in oxidative enzyme activity of Sorbus and tayberry cultivars during cold storage. Acta Univ. Latv. 745: 179-186.

Lambardi M., Benelli C., De Carlo A., Previati A., Da Re F., Giannini M. 2006. Biotechnologies for the preservation of selected red chicory (Cichorum intybus L.) lines. Acta Hort. 725: 311-318.

Lewis D.H., Smith D.C. 1967. Sugar alcohols (polyols) in fungi and green plants. New Phytol. 66: 143-184.

Lipavska H., Vreugdenhil D. 1996. Uptake of mannitol from the media by in vitro grown plants. Plant Cell Tissue Organ Cult. 45: 103-107.

Mitoi E.M., Holobiuc I., Blîndu R. 2009. The effect of mannitol on antioxidative enzymes in vitrolong term cultures of Dianthus tenuifolius and Dianthus spiculifolius. Rom. J. Biol. Plant Biol. 54: 25-33.

Molassiotis A.N., Sotiropoulos T., Tanou G., Kofidis G., Diamantidis G., Therios I. 2006. Antioxidant and anatomical responses in shoot culture of the apple rootstock MM 106 
treated with $\mathrm{NaCl}, \mathrm{KCl}$, mannitol or sorbitol. Biol. Plant. 50: $61-68$.

Morgan G.A., Leech N.L., Gloeckner G.W., Barrett K.C. 2004. SPSS for Introductory Statistics: Use and Interpretation. Lawrence Erlbaum, 211 p.

Negash A., Krens F., Schaart J., Visser B. 2001. In vitro conservation of enset under slow growth conditions. Plant Cell Tissue Organ Cult. 66: 107-111.

Pereira A.M.S., Amiu S.F., Bertoni B.W., Moraes R.M., Franca S.C. 2003. Micropropagarion of Anemopaegma arvense: conservation of an endangered medical plant. Planta Med. 69: 571-573.

Rolland F., Moore B., Sheen J. 2002. Sugar sensing and signaling in plants. Plant Cell 14: S185-S205.
Steinitz B. 1999. Sugar alcohols display nonosmotic roles in regulation morphogenesis and metabolism in plants that do not produce polyols as primary photosynthetic products. $J$. Plant Physiol. 155: 1-8.

Voračkova Z., Lipavska H., Konečny P. 1998. The efficiency of transfer of plants cultivated in vitro to ex vitro conditions as affected by sugar supply. Biol Plant. 41: 507-513.

Welander M., Pawlicki N. 1994. Carbon compounds and their influence on in vitro growth and organogenesis. In: Lumsden P.J., Nicholas J.R., Davies W.J. (eds) Physiology, Growth and Development of Plants in Culture. Springer Science + Business Media, Dordrecht, pp. 83-93.

Xiong L., Zhu J.K. 2002. Molecular and genetic aspects of plant responses to osmotic stress. Plant Cell Environ. 25: 131-139. 